\title{
UIT DE PERS
}

Geesten in Paramaribo. - „Het onderwijs verheldert de geesten der menschen en naarmate dit geschiedt, wordt het geloof aan de geestenwereld minder. Maar dit proces gaat heel langzaam. Dit geldt niet alleen voor Suriname, dit geldt voor alle landen. Het bijgeloof is nog lang niet uitgeroeid, maar wij mogen al tevreden zijn als wij zien, dat het opkomend geslacht op dit gebied reeds heel andere begrippen heeft dan de ouderen van dagen.

Die ouderen, zij zullen het bijgeloof tot hun graf mededragen.

Hoevelen zijn er niet, die tot heden voor geen geld bepaalde punten der stad zouden durven passeeren bij nacht. Punten, waar, volgens oude overlevering, geesten schuilen, die op bepaalde tijden, natuurlijk altijd des nachts, te voorschijn komen.

Zeer bekend is bijvoorbeeld de Jorka (geest) die schuilt onder Froweinkokro. Dit is de koker die zich bevindt in de Zwartenhovenbrugstraat nabij het achtererf van de drukkerij Heyde. Volgens sommigen houdt daar des nachts een officier te paard de wacht: Een bruine officier. Men weet zelfs, dat hij behoort tot de schutterij. Maar de oude Seymonson, zaliger nagedachtenis - die dezen geest gezien en gesproken heeft - verklaart, dat het geen ruiter te paard is, maar een mensch met paardepooten. Op een nacht, toen hij als agent van politie de ronde deed, ontmoette hij bij gemelden koker een rijzige figuur, die op hem toetrad, met het verzoek om wat vuur. De agent, niets kwaads vermoedend, meende, dat de ander zijn sigaar wilde opsteken. Hij streek een lucifer aan en zag toen - tot zijn grooten schrik - iemand voor zich staan op paardevoeten. Het gevolg van deze ontmoeting was, dat de agent zich spoedig. . . . uit de voeten maakte.

Van het Kerkplein is bekend, dat daar des nachts een blanke rondrijdt op een witten schimmel.

Aardiger is de legende betreffende de Wagenwegstraat. Op de plaats waar vroeger het wachthuisje stond van de brandweer, komen, volgens de legende, des nachts een wit varken met twaalf biggetjes te voorschijn. Dat zijn werkelijk heel gemoedelijke vertegenwoordigers van de geestenwereld.

Ernstiger is de zaak in de Gravenstraat. Ter plaatse waar vroeger de oude kraamzaal stond (waar nu de Hendrikschool is) ziet men des nachts - altijd op hetzelfde uur, tusschen twee en drie - een formeele Anitri Beri (Herrnhutter begrafenis).

En wie des nachts de Viottenbrug passeert bij Charlesburg en dan een grooten witten hond ziet, wachte zich wel dit dier toe te spreken, want in deze gedaante vertoont zich, volgens de legende, de geest van deze plaats.

In de Rust en Vredestraat bij de Limesgracht waart tot den huidigen dag een vrouw rond, in blauw gewaad, met een bundel op het hoofd. Het is 
nog niet zoo lang geleden, dat twee agenten, die zich in deze buurt verdekt hadden opgesteld, midden in den nacht een vrouw onhoorbaar zagen naderen. Op een gegeven oogenblik stond de gedaante stil. Het was, of zij onraad had bemerkt. $\mathrm{Zij}$ keerde zich om en de agenten - thans overtuigd, dat zij met een dievegge te doen hadden - liepen haar na. De gedaante versnelde den pas. De agenten deden hetzelfde. Het werd een wilde jacht en op het oogenblik, dat de agenten meenden de vrouw te zullen grijpen, verdween zij plotseling. De beambten doorzochten de geheele omgeving, tot zelfs de trenzen, doch konden geen spoor ontdekken. Terwijl zij nog aan het zoeken waren, kwam een bekende voorbij. $\mathrm{Zij}$ vertelden hem hun wedervaren, waarop hun vriend in luid lachen uitbarstte. Gij kunt lang zoeken, verklaarde hij. Wat gij achtervolgd hebt, de vrouw in het blauw, met een bundel op het hoofd, dat is de gedaante van den geest, die steeds in deze buurt rondzwerft!

Doch niet ieder heeft het geluk — of ongeluk — om geesten te kunnen zien! De personen aan wie dit beschoren is, worden aangeduid met de naam ,,sakka-pikien” oftewel tweelingen ${ }^{1}$ ).

Dat bij al deze verhalen de verbeelding een groote rol speelt, spreekt vanzelf. Al die zoogenaamde bovennatuurlijke zaken, vinden gewoonlijk op de meest natuurlijke wijze een verklaring, als men den moed heeft om tot de kern door te dringen. Zoo bijvoorbeeld gebeurde het op een regenachtigen avond, dat twee vrouwen bij de Bokkobrug aan de $Z$ wartenhovenbrugstraat plotseling een geest zagen. $Z_{i j}$ namen gillende de vlucht, doch werden door den geest teruggeroepen, die zich ontpopte als een inspecteur van politie, die wegens het slechte weder een kapmantel had omgedaan. Had de inspecteur de vluchtelingen niet toegesproken, zij zouden gezworen hebben een slechte verschijning te hebben gezien"....

De West, 28 Januari 1926

1) Niet juist. Sakka pikien zijn kinderen die geheel of voor een groot deel in de eivliezen geboren worden. Zie Encycl. v. Nederl. West-Indie, bl. 617.

RED. W. I. GIDS 